\title{
Pendekatan Regresi Data Panel untuk Pemodelan Jumlah Angkatan Kerja dan Penanaman Modal Luar Negeri terhadap PDRB Provinsi di Indonesia
}

\author{
Muhammad Syukron ${ }^{1}$ and Hafidz Muhammad Fahri ${ }^{2}$ \\ ${ }^{1,2}$ Program Studi Statistika, Universitas Diponegoro, Semarang \\ msyukron.dzeko@gmail.com
}

\begin{abstract}
Indonesia is a country with great economic potency. Indonesia has a vast area and abundant natural products, but until now Indonesia is still a developing country. The Indonesian economy is defeated by other countries such as Japan, China and South Korea even by the neighboring country, Singapore. Increasing the national economy can be started from improving the regional economy which can be measured by gross regional domestic product (GRDP). Indonesia will experience a demographic bonus in 2045 so that the population of productive age is expected to contribute a lot to economic growth. The large number of productive age population must be balanced with the availability of jobs so that this momentum can be fully utilized. Foreign investment can be a solution when domestic capital is insufficient in financing economic activities. In addressing this phenomenon, a statistical analysis of panel data regression was conducted to see the relationship between independent variables, namely the number of labor force and realization of foreign investment, and a dependent variable, namely GRDP at constant prices in 2010 for every province in Indonesia. We use time series data in 2015-2017 and crosssectional data of 34 provinces in Indonesia taken from BPS official website. The estimation result shows that both independent variables partially and fully have a significant effect on the GRDP with an adjusted $R^{2}$ of $99.86 \%$.
\end{abstract}

Keywords: Labor force, regression, panel data, foreign capital, GRDP.

\section{Pendahuluan}

Indonesia merupakan negara dengan potensi ekonomi yang besar. Indonesia memiliki wilayah yang luas dan hasil alam yang melimpah, namun hingga saat ini Indonesia masih tergolong negara yang berkembang. Oleh karena itu, perekonomian Indonesia haruslah ditingkatkan melalui Indonesia Emas 2045.

Indonesia Emas 2045 adalah suatu upaya dalam membangun generasi emas yang dimana adalah sebuah konsep penerapan untuk menyiapkan suatu generasi penerus bangsa Indonesia pada 100 tahun emas Indonesia merdeka antara tahun 1945 sampai tahun 2045. Adapun salah satu cara atau kunci sukses mewujudkan Indonesia Emas 2045 yang dapat dilakukan oleh pemuda dalam ketatnya persaingan di dunia global adalah dengan peningkatan produk-produk lokal sehingga bisa bersaing dengan produk-produk luar. Indonesia di tahun 2045, 31 tahun lagi, dari berbagai sumber dikatakan memiliki "bonus" demografi yang terus berlanjut dan akan berkontribusi atau sebaliknya berbencana pada berbagai sektor. Salah satu kontribusi bonus tersebut adalah pada sektor 
pertumbuhan ekonomi yang akan mengalami masa kejayaan, seperti ungkapan bahwa "In 2045 Indonesia is better than Brazil and China".

Presiden Joko Widodo mengatakan bahwa berdasarkan sejumlah kalkulasi, Indonesia akan bertengger sebagai satu dari lima negara dengan ekonomi terkuat di dunia pada tahun 2045. Indonesia akan mengalami bonus demografi pada tahun 2045, pada saat itu Indonesia didominasi oleh penduduk usia produktif sehingga diharapkan penduduk ini bisa banyak berkontribusi ke pertumbuhan ekonomi.

Pertumbuhan penduduk di suatu negara sangat dipengaruhi oleh mortalitas, fertilasi serta migrasi. Pertumbuhan penduduk akan memberi akibat pada aspek-aspek kehidupan manusia seperti aspek biotik atau sumber daya alam (SDA). Pertumbuhan penduduk yang tinggi akan memberikan dampak positif yaitu sebagai unsur penting dalam menegembangkan kegiatan produksi dan ekonomi. Selain memberikan dampak yang positif, pertumbuhan penduduk juga memberikan dampak yang negatif dalam berbagai aspek yang nantinya akan memiliki pengaruh satu sama lain. Apabila Bonus demografi yang akan dialami Indonesia tidak diimbangi dengan jumlah lapangan pekerjaan yang ada, maka yang akan terjadi hanyalah meningkatnya jumlah pengangguran. Efek buruk dari pengangguran ialah mengurangi pendapatan masyarakat yang pada akhirnya mengurangi tingkat kemakmuran yang telah dicapai seseorang. Semakin turunnya kesejahteraan masyarakat karena menganggur tentunya akan meningkatkan peluang mereka terjebak dalam kemiskinan karena tidak memiliki pendapatan. Apabila pengangguran di suatu negara sangat buruk, kekacauan politik dan sosial selalu berlaku dan menimbulkan efek yang buruk bagi kesejahteraan masyarakat dan prospek pembangunan ekonomi dalam jangka panjang.

Penanaman modal asing bisa menjadi solusi ketika modal dalam negeri tidak mencukupi dalam pembiayaan kegiatan ekonomi. Investasi diharapkan sebagai penggerak pertumbuhan perekonomian Indonesia. Karena terbatasnya dana yang dimiliki pemerintah, untuk menggerakkan pertumbuhan ekonomi maka peran investasi baik secara investasi dari luar negeri (PMA) maupun dari dalam negeri (PMDN). Penanaman Modal Asing (PMA) merupakan aliran arus modal yang berasal dari laur negeri yang mengalir ke sektor swasta baik yang melalui investasi langsung maupun investasi tidak langsung [1].

Dalam menyikapi fenomena ini maka pada penelitian ini dilakukan analisis statistik regresi data panel untuk melihat hubungan dan pemodelan antara variabel independent yaitu jumlah angkatan kerja dan realisasi investasi penanaman modal luar 
negeri (juta US\$) terhadap variabel dependen yaitu PDRB atas harga konstan 2010 (milyar Rupiah) tiap provinsi di Indonesia 3 tahun terakhir.

\section{Regresi Data Panel}

Ada tiga jenis data yang digunakan dalam riset ekonometri, yaitu:

1. Cross section (antar ruang),

2. Time series (antar waktu), dan

3. Panel data atau pooling data, yaitu gabungan data cross section dan data time series.

Teknik panel data, dengan menggabungkan jenis data cross section dan time series, memberikan beberapa keunggulan dibandingkan dengan pendekatan standar cross section dan time series. Untuk menggambarkan panel data secara singkat, misalkan pada data cross section, nilai dari satu variabel atau lebih dikumpulkan untuk beberapa unit sampel pada suatu waktu waktu. Dalam panel data, unit cross section yang sama di-survey dalam beberapa waktu.

Data panel merupakan data hasil observasi yang menggabungkan antara data cross section dan time series. Data time series biasanya meliputi satu objek tetapi meliputi beberapa periode (harian, bulanan, kuartalan, atau tahunan). Data cross section terdiri atas beberapa atau banyak objek,sering disebut responden dengan beberapa jenis data (laba, biaya iklan, laba ditahan, dan tingkat investasi) dalam suatu periode waktu tertentu.

Model dengan data cross section

$y_{i}=\alpha+\beta x_{i}+\varepsilon ; i=1,2, \ldots, N ; N$ : banyaknya data cross section

Model dengan data time series

$y_{t}=\alpha+\beta x_{t}+\varepsilon ; t=1,2, \ldots, T ; T:$ banyaknya data time series

Model dengan data panel

$y_{i t}=\alpha_{i t}+\beta x_{i t}+u_{i t} ; i=1,2, \ldots, N ; t=1,2, \ldots, T$

dimana :

$N$ : banyaknya data cross section

$T$ : banyaknya data time series

Secara prinsip, jika kita mendapatkan data lebih banyak perusahaan akan kita bias melakukan regresi data cross section pada tahun tertentu saja. Disamping itu, kita juga biasa melakukan regresi menggunakan data time series untuk mengetahui perilaku $(y)$ 
dari tiap objek. Namun, alangkah baiknya jika kita mengamati perilaku dari seluruh objek dengan menggunakan data panel.

Model regresi dengan data panel, secara umum mengakibatkan mempunyai kesulitan dalam spesifikasi modelnya. Residualnya akan mempunyai tiga kemungkinan yaitu residual time series, cross section maupun gabungan keduanya. Ada beberapa metode yang bisa digunakan untuk mengestimasi model regresi dengan data panel, yaitu pendekatan common effect, fixed effect, dan random effect.

Estimasi model pada persamaan data panel tergantung pada asumsi yang kita buat mengenai intersep, koefisien kemiringan (slope), dan error term $u_{i t}$. Ada beberapa kemungkinan :

1. Asumsi bahwa intersep dan koefisien slope (kemiringan) adalah konstan antar waktu (time) dan ruang (space) dan error term mencakup perbedaan sepanjang waktu dan individu (ruang).

2. Koefisien slope konstan tetapi intersep bervariasi antar individu saja atau bervariasi antar individu dan waktu.

3. Intersep maupun koefisien slope bervariasi antar individu saja atau bervariasi antar individu dan waktu.

2.1. Common Effect Model (CEM). Teknik yang paling sederhana untuk mengestimasi data panel adalah hanya mengkombinasikan data time series dan cross section dengan menggunakan metode OLS dikenal dengan estimasi common effect. Dalam pendekatan ini tidak memperhatikan dimensi individu maupun waktu (intersep dan koefisien slope nya konstan). Persamaan common effect model (CEM) dapat dituliskan dengan

$$
y_{i t}=\alpha+\sum_{k=1}^{K} \beta_{k} X_{k_{i t}}+u_{i t}, \text { untuk } i=1,2, \ldots, N ; t=1,2, \ldots, T ; k=1,2, \ldots, K
$$
dengan

$y_{i t}=$ Variabel respon pada unit observasi ke- $i$ dan waktu ke- $t$

$X_{k_{i t}}=$ Nilai variabel independen ke- $k$ untuk cross section ke- $i$ dan tahun ke- $t$

$\beta_{k}=$ Koefisien slope

$\alpha \quad=$ Intersep model regresi

dimana

$K=$ Banyaknya variabel independen

$N$ = Banyaknya observasi

$T$ = Banyaknya periode tahun 


$$
u_{i t}=\text { Galat pada unit observasi ke- } i \text { dan waktu ke- } t
$$

2.2. Fixed Effects Model (FEM). Sebelumnya diasumsikan bahwa intersep maupun slope adalah sama baik waktu maupun antar individu. Namun, asumsi ini sangat jauh dari realita sebenarnya. Karakteristik antar individu dan waktu jelas akan berbeda. Salah satu cara paling sederhana mengetahui adanya perbedaan adalah dengan mengasumsikan bahwa intersep adalah berbeda antar individu dan antar waktu sedangkan slopenya konstan. Model FEM dapat dinyatakan dengan persamaan berikut ini.

Slopenya konstan tetapi intersep bervariasi antar individu

$$
Y_{i t}=\alpha_{i}+\sum_{k=1}^{K} \beta_{k} X_{k_{i t}}+u_{i t} \text {, untuk } i=1,2, \ldots, N ; t=1,2, \ldots, T ; k=1,2, \ldots, K
$$

Slopenya konstan tetapi intersep bervariasi antar individu dan antar waktu

$$
Y_{i t}=\alpha_{i t}+\sum_{k=1}^{K} \beta_{k} X_{k_{i t}}+u_{i t} \text {, untuk } i=1,2, \ldots, N ; t=1,2, \ldots, T ; k=1,2, \ldots, K
$$

Model yang mengasumsikan adanya perbedaan intersep di dalam persamaan diatas tersebut dikenal dengan model regresi fixed effect (FEM). Pemodelan FEM menggunakan teknik penambahan variabel dummy yang biasa disebut dengan teknik least square dummy variables (LSDV).

2.3. Random Effect Model (REM). Bila pada fixed effect model perbedaan antar individu dan waktu dicerminkan lewat intersep, maka pada random effect model diakomodasi lewat error. Metode pendugaan regresi data panel pada random effect model (REM) menggunakan metode generalized least square (GLS), dapat dinyatakan dengan persamaan berikut.

Intersep dan slope bervariasi antar individu

$$
Y_{i t}=\alpha_{i}+\sum_{k=1}^{K} \beta_{k_{i}} X_{k_{i t}}+u_{i t} \text {, untuk } i=1,2, \ldots, N ; t=1,2, \ldots, T ; k=1,2, \ldots, K
$$

Intersep dan slope bervariasi antar individu

$$
Y_{i t}=\alpha_{i t}+\sum_{k=1}^{K} \beta_{k_{i t}} X_{k_{i t}}+u_{i t} \text {, untuk } i=1,2, \ldots, N ; t=1,2, \ldots, T ; k=1,2, \ldots, K
$$

2.4. Pemilihan Model. Pemilihan model yang paling tepat diantara CEM, FEM, dan REM dilakukan tahapan sebagai berikut:

1. Uji Chow

Uji Chow dilakukan untuk menentukan apakah model common effect lebih baik digunakan dari pada metode fixed effect. Dalam hal ini hipotesisnya adalah

$H_{0}$ : Model CEM yang sesuai

$H_{l}$ : Model FEM yang sesuai 


\section{Uji Hausman}

Uji Hausman dilakukan untuk menentukan apakah model fixed effect lebih baik digunakan dari pada metode random effect. Dalam hal ini ditetapkan hipotesis sebagai berikut:

$$
\begin{aligned}
& H_{0} \text { : Model REM yang sesuai } \\
& H_{l} \text { : Model FEM yang sesuai }
\end{aligned}
$$

3. Uji Breusch Pagan - Legrange Multiplier (LM Test)

Uji Signifikansi random effect dilakukan untuk menentukan apakah model Random Effect lebih baik digunakan dari pada metode common effect. Dalam hal ini ditetapkan hipotesis adalah

$H_{0}$ : Model CEM yang sesuai

$H_{1}$ : Model REM yang sesuai

2.5. Uji Asumsi Klasik. Istilah klasik dalam ekonometrika digunakan untuk menunjukkan serangkaian asumsi-asumsi dasar yang dibutuhkan untuk menjaga agar pendekatan yang digunakan menghasilkan estimator yang paling baik. Pada teorinya, jikalau terdapat asumsi yang tidak terpenuhi maka harus dilakukan pengatasan asumsi. Asumsi yang harus dipenuhi adalah

1. Normalitas

Uji normalitas dimaksudkan untuk menguji apakah nilai residual dalam persamaan regresi berdistribusi normal atau tidak. Dalam modul ini digunakan uji normalitas yaitu Jarque Bera dengan hipotesis:

$H_{0}$ : Residual berdistribusi normal

$H_{l}$ : Residual tidak berdistribusi normal

2. Multikolinieritas

Uji multikolinieritas dimaksudkan untuk menguji apakah terdapat hubungan yang signifikan antar variabel independen yang ada. Dalam modul ini untuk mengetahui hal tersebut dilihat dari matriks korelasi antar variabel independen.

\section{Heteroskedastisitas}

Uji heteroskedastisitas dimaksudkan untuk menguji apakah ada varian dari residual yang berbeda yang dapat membiaskan hasil estimasi. Dalam modul ini digunakan uji heteroskedastisitas yaitu Glejser dengan hipotesis:

$H_{0}$ : Residual bersifat homoskedastisitas

$H_{l}$ : Residual bersifat heteroskedastisitas 
4. Autokorelasi

Uji autokorelasi dimaksudkan untuk menguji apakah ada korelasi antara serangkaian data observasi yang diuraikan waktu (time series) dan individu (cross section). Dalam modul ini digunakan uji autokorelasi yaitu Durbin Watson dengan hipotesis sebagai berikut:
$H_{0}$ : Tidak terjadi autokorelasi
$H_{l}$ : Terjadi autokorelasi

2.6. Uji Goodness of Fit. Ketepatan fungsi regresi dalam menaksir nilai actual dapat diukur dari goodness of fit suatu model persamaan regresinya. Pengukuran goodness of fit tersebut dapat dilakukan melalui nilai statistik F, nilai statistik t, dan koefisien korelasi.

1. Pengujian koefisien regresi secara bersama ( Uji F )

Uji F dilakukan untuk mengetahui apakah variabel-variabel independen secara keseluruhan atau bersama-sama signifikan dalam mempengaruhi variabel dependen.

2. Uji signifikansi parameter individual ( Uji t )

Uji t dilakukan untuk mengetahui seberapa jauh pengaruh satu variabel secara individu dalam mempengaruhi variabel dependen.

3. Uji koefisien determinasi $\left(R^{2}\right)$

Uji $R^{2}$ dilakukan untuk mengetahui seberapa jauh variasi variabel independen dapat menerangkan dengan baik variasi variabel dependen.

2.7. Penelitian Terdahulu. Penelitian terdahulu mengenai PDRB yang kami amati adalah milik Yozi Aulia Rahman dan Ayunda Lintang Chamelia (mahasiswa Universitas Negeri Semarang) yang berjudul "Faktor-faktor yang mempengaruhi PDRB kabupaten/ kota Jawa Tengah tahun 2008-2012”. Karya ilmiah tersebut menggunakan metode analisis regresi data panel dengan variabel respon yaitu PDRB dan variabel-variabel independennya yaitu Tabungan, Kredit, Pendapatan Asli Daerah (PAD) dan Belanja Daerah. Hasil estimasi menunjukkan bahwa hasil analisis regresi pada $\alpha=5 \%$ menunjukkan bahwa secara parsial variabel tabungan dan kredit berpengaruh signifikan, sedangkan variabel PAD, dan Belanja Daerah tidak signifikan terhadap PDRB kabupaten/kota di Provinsi Jawa Tengah tahun 2008-2012.

Dari penelitian tersebut akan dilakukan analisis regresi data panel mengenai PDRB, namun cakupannya diperluas menjadi tiap Provinsi di Indonesia, selain itu data yang digunakan juga lebih baru yaitu data tahun 2015,2016, dan 2017. Berkenaan dengan 
isu bonus demografi Indonesia emas 2045 maka kami memilih variabel bebas yaitu jumlah angkatan kerja serta investasi modal luar negeri.

\section{Hasil dan Pembahasan}

\subsection{Eksplorasi data}

Tabel 1. Nilai maksimum, minimum, dan rata-rata

\begin{tabular}{|c|c|c|c|c|c|c|c|c|c|}
\hline & \multicolumn{3}{|c|}{ Jumlah angkatan kerja } & \multicolumn{3}{|c|}{$\begin{array}{l}\text { PDRB atas harga konstan } 2010 \\
\text { (milyar rupiah) }\end{array}$} & \multicolumn{3}{|c|}{$\begin{array}{c}\text { Invetsasi modal luar } \\
\text { negeri (juta US\$) }\end{array}$} \\
\hline & 2015 & 2016 & 2017 & 2015 & 2016 & 2017 & 2015 & 2016 & $\begin{array}{l}201 \\
7\end{array}$ \\
\hline Max & $\begin{array}{l}2058635 \\
6 \\
\end{array}$ & $\begin{array}{l}2107589 \\
9\end{array}$ & $\begin{array}{l}2239100 \\
3\end{array}$ & $\begin{array}{l}1454563, \\
85\end{array}$ & $\begin{array}{l}1540078, \\
20\end{array}$ & $\begin{array}{l}1635855, \\
75\end{array}$ & $\begin{array}{l}5738, \\
7\end{array}$ & $\begin{array}{l}5470, \\
9\end{array}$ & $\begin{array}{l}514 \\
2,9\end{array}$ \\
\hline Min & 283102 & 288522 & 330731 & 20380,30 & 21556,68 & 23210,86 & 2,0 & 12,7 & 11,4 \\
\hline $\begin{array}{l}\text { Ave } \\
\text { rage }\end{array}$ & 3599412 & 3689522 & 3766551 & $\begin{array}{l}265681,4 \\
3\end{array}$ & $\begin{array}{l}279403,8 \\
2\end{array}$ & $\begin{array}{l}294006,0 \\
9\end{array}$ & 861,1 & 851,9 & $\begin{array}{l}948, \\
2\end{array}$ \\
\hline
\end{tabular}

Dari Tabel 1 didapat nilai maksimal, minimal dan rata-rata dari jumlah angkatan kerja, PDRB atas harga konstan 2010, dan investasi modal luar negeri dari tahun 2015 hingga 2017. Jumlah angkatan kerja terbanyak pada tahun 2015, 2016, dan 2017 berada di Jawa Barat dengan nilainya berturut-turut 20.586.356, 21.075.899, dan 22.391.003. Sedangkan jumlah angkatan kerja paling sedikit 3 tahun terakhir yaitu provinsi kalimantan utara dengan jumlah sebagai berikut dari 2015 hingga 2017 yaitu 283.102, 288.522, dan 330.731. Rata-rata jumlah angkatan kerja tiap provinsi di Indonesia 3 tahun terakhir dari 2015 berturut-turut adalah 3.599.412, 3.689.522, dan 3.766.551.

Untuk PDRB atas harga konstan 3 tahun terakhir DKI Jakarta selalu menjadi yang tertinggi yaitu sebesar 1.454.563,85; 1.540.078,2; dan 1.635.855,75 (dalam milyar rupiah). Sedangkan PDRB provinsi terendah 3 tahun terakhir yaitu provinsi Maluku Utara dengan nilai nya berturut-turut dari 2015 adalah 20.380,3; 21.556,68; dan 23.210,86 (dalam milyar rupiah). Rata-rata PDRB tiap provinsi di Indonesia dari 2015 hingga 2017 berurutan adalah sebesar 265.681,43; 279.403,82; dan 294.006,09 (dalam milyar rupiah).

Investasi asing tertinggi di Indonesia 3 tahun terakhir berada di Jawa Barat yaitu sebesar 5.378,7; 5470,9; dan 5142,9 (juta US\$). Sedangkan investasi asing terendah pada tahun 2015 berada di Gorontalo yaitu sebesar 2 juta US\$, tahun 2016 di Sulawesi Tengah yaitu sebesar 12,7 juta US\$, dan tahun 2017 kembali Gorontalo yaitu sebesar 11,4 juta US\$. Rata-rata investasi asing di Indonesia tiap provinsi 3 tahun terakhir adalah sebesar 861,$1 ; 851,9 ;$ dan 948,2 (juta US\$) 


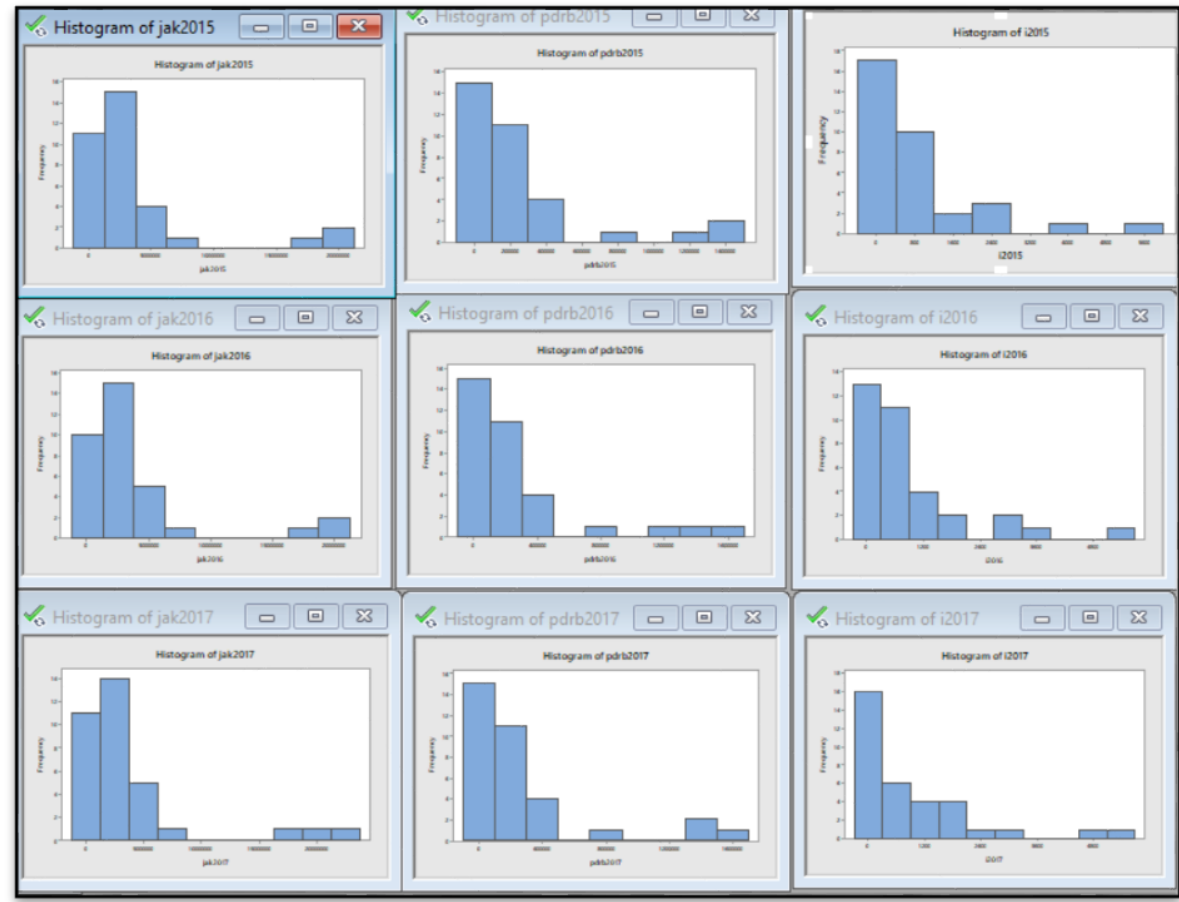

Gambar 1. Histogram variabel dependen dan independen

Dari histogram jumlah angkatan kerja, pdrb dan investasi modal luar negeri tampak histogram tidak simetris seperti lonceng dan cenderung positive skewed sehingga kemungkinan tidak berdistribusi normal maka variabel dependent $(Y)$ ditransformasi dengan pangkat $1 / 4 . \mathrm{Y}^{*}=\mathrm{Y}^{1 / 4}$.

3.2. Melakukan Uji Chow untuk memilih kedua model diantara CEM dan FEM.

a. Jika $H_{0}$ diterima, maka Model common effect.

b. Jika $H_{0}$ ditolak, maka Model fixed effect.

Redundant Fixed Effects Tests

Equation: Untitled

Test cross-section fixed effects

\begin{tabular}{lrrr}
\hline \hline Effects Test & Statistic & d.f. & Prob. \\
\hline \hline Cross-section F & 684.423145 & $(33,66)$ & 0.0000 \\
Cross-section Chi-square & 595.511403 & 33 & 0.0000 \\
\hline \hline
\end{tabular}

Gambar 2. Uji Chow 
Dari Gambar 2 didapat nilai probabilitas chi square yang kurang dari $\alpha=5 \%$ sehingga $H_{0}$ ditolak maka model yang terpilih adalah fixed effect model. Selanjutnya dilakukan uji haussman.

3.3. Melakukan Uji Hausman untuk memilih kedua model diantara REM dengan FEM

a. Jika $H_{0}$ diterima, maka model random effect.

b. Jika $H_{0}$ ditolak, maka model fixed effect.

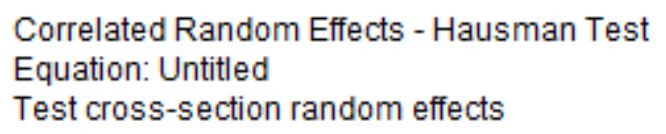

\begin{tabular}{lrrr}
\hline \hline Test Summary & Chi-Sq. Statistic & Chi-Sq. d.f. & Prob. \\
\hline \hline Cross-section random & 5.922002 & 2 & 0.0518 \\
\hline \hline
\end{tabular}

Gambar 3. Uji Haussman

Dari Gambar 3 didapat nilai probabilitas chi square yang kurang dari $\alpha=10 \%$ sehingga $\mathrm{HO}$ ditolak maka model yang terpilih adalah fixed effect model.

3.4. Verifikasi model. Setelah terpilih model fixed effect maka selanjutnya dilakukan verifikasi model yaitu dengan uji asumsi. Uji asumsi yang pertama adalah normalitas residual. Adapun uji ini dilakukan dengan Jarque-Bera.

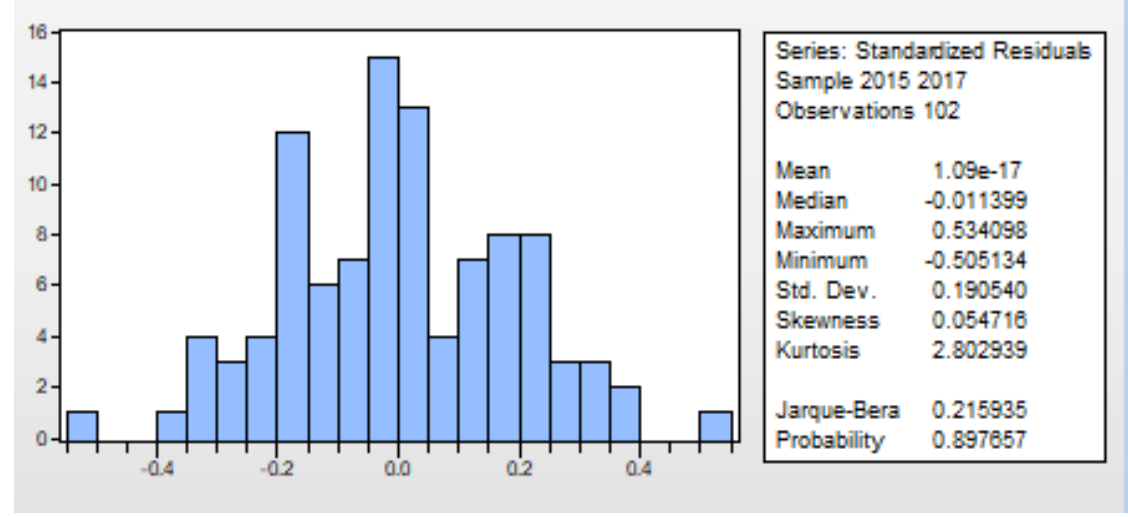

Gambar 4. Normality test residual

Dari Gambar 4 tampak bahwa nilai Jarque-Bera=0,215935 dan probabilitasnya 0,897657 . Karena nilai probabilitas ini lebih besar dari $\alpha=5 \%$ maka $\mathrm{H}_{0}$ diterima sehingga residual berdistribusi normal. 
Selanjutnya adalah uji multikolinieritas yaitu dengan melihat nilai korelasi antar variabel bebas yaitu jumlah angkatan kerja dan investasi modal luar negeri. Apabila nilai korelasi mendekati 1 maka dapat dikatakan bahwa terdapat multikolinieritas.

\begin{tabular}{|c|c|c|l|l|l|}
\hline \multicolumn{5}{|c|}{ Correlation } & \\
\hline & $\mathrm{X} 1$ & $\mathrm{X} 2$ & & \\
\hline $\mathrm{X} 1$ & 1.000000 & 0.564126 & & \\
\hline $\mathrm{X} 2$ & 0.564126 & 1.000000 & & \\
\hline
\end{tabular}

Gambar 5. Uji korelasi variabel bebas

Dari Gambar 5 tampak bahwa nilai korelasi antar variabel bebas sebesar 0,564 yang berarti tidak kuat atau tidak mendekati 1 sehingga asumsi non multikolinieritas terpenuhi.

Asumsi yang ketiga adalah homoskedastisitas. Adapun uji yang dilakukan adalah uji geyser yaitu dengan meregresikan kedua variabel independent (jumlah angkatan kerja dan investasi modal luar negeri) terhadap nilai absolut dari residual sebagai variabel dependen. Apabila nilai koefisien dari variabel independen signifikan maka dapat dikatakan terdapat heteroskedastisitas.

\begin{tabular}{|c|c|c|c|c|}
\hline \multicolumn{5}{|c|}{$\begin{array}{l}\text { Dependent Variable: RESABS } \\
\text { Method: Panel Least Squares } \\
\text { Date: } 08 / 31 / 18 \text { Time: } 06: 52 \\
\text { Sample: } 20152017 \\
\text { Periods included: } 3 \\
\text { Cross-sections included: } 34 \\
\text { Total panel (balanced) observations: } 102\end{array}$} \\
\hline Variable & Coefficient & Std. Error & t-Statistic & Prob. \\
\hline $\mathrm{C}$ & 0.365558 & 0.251185 & 1.455332 & 0.1503 \\
\hline $\mathrm{X} 1$ & $5.23 \mathrm{E}-05$ & $3.79 \mathrm{E}-05$ & 1.379390 & 0.1724 \\
\hline X2 & $-7.07 \mathrm{E}-08$ & $6.64 \mathrm{E}-08$ & -1.064440 & 0.2910 \\
\hline
\end{tabular}

Gambar 6. Uji Geyser

Dari Gambar 6 tampak nilai probabilitas koefisien $x 1$ adalah 0,1724 dan probabilitas koefisien $x 2$ adalah 0,291 . Kedua probabilitas tersebut lebih besar dari $\alpha=5 \%$ sehingga tidak signifikan maka dapat disimpulkan bahwa asumsi homoskedatsias terpenuhi.

Asumsi non autokorelasi terpenuhi apabila nilai Durbin Watson berada diantara $d u$ dan 4-du. 
Volume 1 No. 2 November 2018

$0<d<d l$ (autokorelasi positif)

$D l<d<d u$ (ragu-ragu)

$D u<d<4-d u$ (menerima $H_{0}$ yaitu tidak ada autokorelasi)

$4-d u<d<4-d l$ (ragu-ragu)

$4-d l<d<4$ (autokorelasi negatif)

Apabila keputusan berada didaerah ragu-ragu maka bisa dilakukan uji run test.

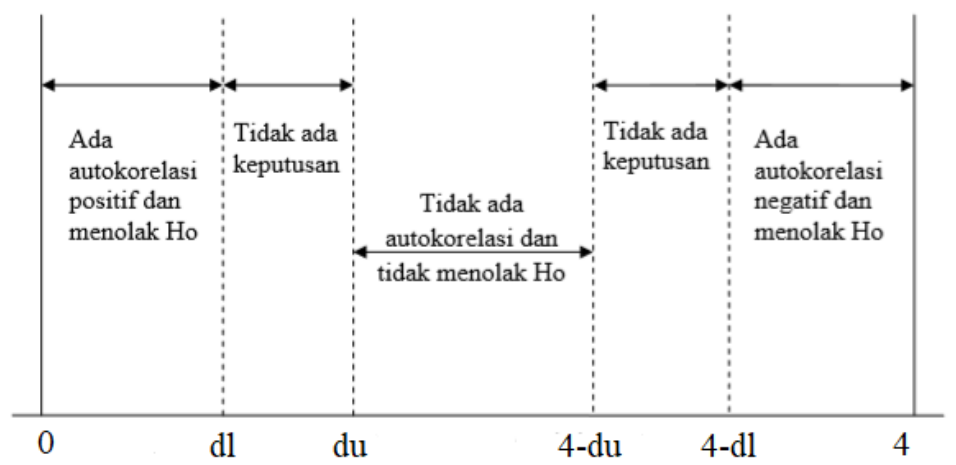

Gambar 7. Uji autokorelasi

Adapun untuk melihat nilai Durbin Watson yaitu dengan melihat jumlah observasi dan jumlah variabel bebasnya. Untuk nilai durbin watson sendiri dapat dilihat di Gambar 8 sebagai output dari Eviews 9.

\begin{tabular}{|c|c|c|c|c|}
\hline \multicolumn{5}{|c|}{$\begin{array}{l}\text { Dependent Variable: KY } \\
\text { Method: Panel Least Squares } \\
\text { Date: } 08 / 31 / 18 \text { Time: } 06: 54 \\
\text { Sample: } 20152017 \\
\text { Periods included: } 3 \\
\text { Cross-sections included: } 34 \\
\text { Total panel (balanced) observations: } 102\end{array}$} \\
\hline Variable & Coefficient & Std. Error & t-Statistic & Prob. \\
\hline $\mathrm{C}$ & 17.46997 & 0.517333 & 33.76929 & 0.0000 \\
\hline $\mathrm{X} 1$ & 0.000159 & $7.82 E-05$ & 2.038742 & 0.0455 \\
\hline $\mathrm{X} 2$ & $6.77 \mathrm{E}-07$ & $1.37 E-07$ & 4.946978 & 0.0000 \\
\hline \multicolumn{5}{|c|}{ Effects Specification } \\
\hline \multicolumn{5}{|c|}{ Cross-section fixed (dummy variables) } \\
\hline R-squared & 0.999056 & \multicolumn{2}{|c|}{ Mean dependent var } & 20.10505 \\
\hline Adjusted R-squared & 0.998556 & \multicolumn{2}{|c|}{ S.D. dependent var } & 6.203055 \\
\hline S.E. of regression & 0.235708 & \multicolumn{2}{|c|}{ Akaike info criterion } & 0.218122 \\
\hline Sum squared resid & 3.666860 & \multicolumn{2}{|c|}{ Schwarz criterion } & 1.144583 \\
\hline Log likelihood & 24.87576 & \multirow{2}{*}{\multicolumn{2}{|c|}{$\begin{array}{l}\text { Hannan-Quinn criter. } \\
\text { Durbin-Watson stat }\end{array}$}} & 0.593278 \\
\hline F-statistic & 1996.661 & & & 1.786759 \\
\hline Prob(F-statistic) & 0.000000 & \multicolumn{2}{|c|}{ Durbin-Watson stat } & \\
\hline
\end{tabular}

Gambar 8. Fixed Effect model 
Nilai Durbin Watson $=1,786759$, sedangkan dari tabel Durbin Watson dengan $n=102$ (jumlah observasi) dan $k=2$ (jumlah variabel bebas) didapat $d l=1.6376$ dan $d u=1.7175$. maka dapat disimpulkan bahwa nilai durbin watson diantara $d u$ dan 4-du sehingga tidak ada autokorelasi.

\subsection{Uji goodness of fit}

\section{A. Uji F}

- Hipotesis

$H_{0}$ : model tidak cocok

$H_{l}$ : model cocok

- Taraf signifikansi

$\alpha=5 \%$

- Daerah kritis

$H_{0}$ ditolak jika nilai sig $<\alpha=5 \%$

- Keputusan

Dari Gambar 8 tampak bahwa nilai $\operatorname{prob}(F$-statistics $)=0,0000<\alpha=5 \%$ sehingga $H_{0}$ ditolak

- Kesimpulan

Pada taraf signifikansi $\alpha=5 \% H_{0}$ ditolak sehingga model FEM cocok

\section{B. Uji t (signifikansi koefisien $X 1$ )}

- Hipotesis

$H_{0}: \beta 1$ tidak signifikan

$H_{1}: \beta 1$ signifikan

- Taraf signifikansi

$\alpha=5 \%$

- Daerah kritis

$H_{0}$ ditolak jika nilai sig $<\alpha=5 \%$

- Keputusan

Dari Gambar 7 tampak bahwa nilai $\operatorname{prob}(\beta 1)=0,0455<\alpha=5 \%$ sehingga $H_{0}$ ditolak

- Kesimpulan

Pada taraf signifikansi $\alpha=5 \% H_{0}$ ditolak sehingga $\beta 1$ signifikan

\section{Uji t (signifikansi koefisien $X 2$ )}

- Hipotesis

$H_{0}: \beta 2$ tidak signifikan

$H_{l}: \beta 2$ signifikan 
- Taraf signifikansi

$\alpha=5 \%$

- Daerah kritis

$H_{0}$ ditolak jika nilai sig $<\alpha=5 \%$

- Keputusan

Dari Gambar 7 tampak bahwa nilai $\operatorname{prob}(\beta 1)=0,000<\alpha=5 \%$ sehingga $H_{0}$ ditolak

- Kesimpulan

Pada taraf signifikansi $\alpha=5 \% H_{0}$ ditolak sehingga $\beta 2$ signifikan

\section{Koefisien determinasi}

Dilihat dari Gambar 8 tampak nilai $R$ squared sebesar 99,9\% dan untuk $R^{2}$ adjusted sebesar $99,8556 \%$ artinya $X 1$ dan $X 2$ bisa menggambarkan variabel $Y$ sebesar $99,8556 \%$.

\section{E. Intepretasi hasil}

Dalam regresi pengaruh jumlah angkatan kerja dan investasi modal luar negeri terhadap PDRB tiap provinsi di Indonesia tahun 2015 - 2017, dengan menggunakan metode FEM, diperoleh nilai koefisien regresi untuk setiap variabel dalam penelitian dengan persamaan sebagai berikut :

$$
Y^{*}=17,46997+C i+0,0001599 X_{1}+6,77 E-07 X_{2}
$$

dimana

$Y^{*}=Y^{1 / 4}$

$Y=$ Produk domestik regional bruto

$X 1=$ Investasi luar negeri

$X 2=$ Jumlah angkatan kerja

$C i=$ konstanta ke $i$

Untuk mendapatkan nilai $Y$ maka hasil dari input $X 1, X 2$, dan $C i$ akan menghasilkan $Y^{*}$ kemudian $Y^{*}$ dipangkatkan 4. 


\begin{tabular}{|c|c|c|c|c|}
\hline \multicolumn{5}{|c|}{$\begin{array}{l}\text { Dependent Variable: KY } \\
\text { Method: Panel Least Squares } \\
\text { Date: } 08 / 31 / 18 \text { Time: } 06: 54 \\
\text { Sample: } 20152017 \\
\text { Periods included: } 3 \\
\text { Cross-sections included: } 34 \\
\text { Total panel (balanced) observations: } 102\end{array}$} \\
\hline Variable & Coefficient & Std. Error & t-Statistic & Prob. \\
\hline $\mathrm{C}$ & 17.46997 & 0.517333 & 33.76929 & 0.0000 \\
\hline $\mathrm{X} 1$ & 0.000159 & $7.82 E-05$ & 2.038742 & 0.0455 \\
\hline $\mathrm{X} 2$ & $6.77 \mathrm{E}-07$ & $1.37 \mathrm{E}-07$ & 4.946978 & 0.0000 \\
\hline \multicolumn{5}{|c|}{ Effects Specification } \\
\hline \multicolumn{5}{|c|}{ Cross-section fixed (dummy variables) } \\
\hline R-squared & 0.999056 & \multirow{2}{*}{\multicolumn{2}{|c|}{ Mean dependent var }} & 20.10505 \\
\hline Adjusted R-squared & 0.998556 & & & 6.203055 \\
\hline S.E. of regression & 0.235708 & \multicolumn{2}{|c|}{ Akaike info criterion } & 0.218122 \\
\hline Sum squared resid & 3.666860 & \multicolumn{2}{|c|}{ Schwarz criterion } & 1.144583 \\
\hline Log likelihood & 24.87576 & \multicolumn{2}{|c|}{ Hannan-Quinn criter. } & 0.593278 \\
\hline F-statistic & 1996.661 & \multirow{2}{*}{\multicolumn{2}{|c|}{ Durbin-Watson stat }} & 1.786759 \\
\hline Prob(F-statistic) & 0.000000 & & & \\
\hline
\end{tabular}

Gambar 9. Model FEM

Variabel Jumlah angkatan kerja signifikan pada $\alpha=5 \%$ dengan koefisien yang bertanda positif, sehingga dapat dikatakan bahwa meningkatnya jumlah angkatan kerja maka akan meningkatkan PDRB provinsi di Indonesia. dengan melihat keadaan ini maka kita berharap bahwa pada tahun 2045 ketika jumlah angkatan kerja semakin banyak maka akan benar-benar mendongkrak perekonomian Indonesia. kemudian dilihat dari pengaruh parsial Investasi modal asing juga menghasilkan koefisien yang positif, ini berarti bahwa peningkatan penanaman modal asing di Indonesia juga akan memperkuat PDRB provinsi, ketika modal dalam negeri dirasa kurang dan diperlukannya modal asing maka kebijakan ini bisa diambil mengingat investasi modal asing signifikan berpengaruh positif dalam peningkatan PDRB provinsi.

Tabel 2. Konstanta tiap provinsi

\begin{tabular}{|c|c|c|c|c|c|c|c|c|}
\hline $\mathrm{i}$ & Provinsi & $\mathrm{Ci}$ & $\mathrm{i}$ & provinsi & $\mathrm{Ci}$ & $\mathrm{i}$ & provinsi & $\mathrm{Ci}$ \\
\hline 1 & Aceh & $\begin{array}{l}- \\
0,513388\end{array}$ & 13 & Banten & 0,567852 & 25 & $\begin{array}{l}\text { Sulawesi } \\
\text { Utara }\end{array}$ & $\begin{array}{l}- \\
1,74922 \\
8\end{array}$ \\
\hline 2 & $\begin{array}{l}\text { Sumatera } \\
\text { Utara }\end{array}$ & 4,028032 & 14 & $\begin{array}{l}\text { Jawa } \\
\text { Tengah }\end{array}$ & $-1,87972$ & 26 & Gorontalo & $\begin{array}{l}- \\
1,11269 \\
8\end{array}$ \\
\hline 3 & $\begin{array}{l}\text { Sumatera } \\
\text { Barat }\end{array}$ & 0,484755 & 15 & $\begin{array}{l}\text { DI } \\
\text { Yogyakarta }\end{array}$ & 3,156055 & 27 & $\begin{array}{l}\text { Sulawesi } \\
\text { Tengah }\end{array}$ & $\begin{array}{l}2,51583 \\
1\end{array}$ \\
\hline
\end{tabular}




\begin{tabular}{|c|c|c|c|c|c|c|c|c|}
\hline 4 & Riau & 6,463919 & 16 & Jawa Timur & 3,444886 & 28 & $\begin{array}{l}\text { Sulawesi } \\
\text { Selatan }\end{array}$ & $\begin{array}{l}- \\
1,64676 \\
5\end{array}$ \\
\hline 5 & $\begin{array}{l}\text { Kepulauan } \\
\text { Riau }\end{array}$ & 0,288785 & 17 & Bali & 0,032192 & 29 & $\begin{array}{l}\text { Sulawesi } \\
\text { Barat }\end{array}$ & $\begin{array}{l}- \\
5,45339 \\
3\end{array}$ \\
\hline 6 & Jambi & 2,494647 & 18 & $\begin{array}{l}\text { Nusa } \\
\text { Tenggara } \\
\text { Barat }\end{array}$ & $-1,68826$ & 30 & $\begin{array}{l}\text { Sulawesi } \\
\text { Tenggara }\end{array}$ & $\begin{array}{l}- \\
5,06965 \\
8\end{array}$ \\
\hline 7 & $\begin{array}{l}\text { Sumatera } \\
\text { Selatan }\end{array}$ & $\begin{array}{l}- \\
4,227149\end{array}$ & 19 & $\begin{array}{l}\text { Nusa } \\
\text { Tenggara } \\
\text { Timur }\end{array}$ & $-3,44430$ & 31 & Maluku & $\begin{array}{l}- \\
5,24797\end{array}$ \\
\hline 8 & $\begin{array}{l}\text { Kepulauan } \\
\text { Bangka } \\
\text { Belitung }\end{array}$ & 1,205633 & 20 & $\begin{array}{l}\text { Kalimantan } \\
\text { Barat }\end{array}$ & $-0,67618$ & 32 & $\begin{array}{l}\text { Maluku } \\
\text { Utara }\end{array}$ & $\begin{array}{l}- \\
5,73074 \\
1\end{array}$ \\
\hline 9 & Bengkulu & $\begin{array}{l}- \\
3,152915\end{array}$ & 21 & $\begin{array}{l}\text { Kalimantan } \\
\text { Tengah }\end{array}$ & $-1,41988$ & 33 & $\begin{array}{l}\text { Papua } \\
\text { barat }\end{array}$ & $\begin{array}{l}- \\
2,68202 \\
9\end{array}$ \\
\hline 10 & Lampung & 1,918762 & 22 & $\begin{array}{l}\text { Kalimantan } \\
\text { Selatan }\end{array}$ & $-0,47355$ & 34 & Papua & $\begin{array}{l}0,65894 \\
5\end{array}$ \\
\hline 11 & $\begin{array}{l}\text { DKI } \\
\text { Jakarta }\end{array}$ & 13,74083 & 23 & $\begin{array}{l}\text { Kalimantan } \\
\text { Timur }\end{array}$ & 6,982628 & & & \\
\hline 12 & Jawa Barat & 0,811854 & 24 & $\begin{array}{l}\text { Kalimantan } \\
\text { Utara }\end{array}$ & $-2,62774$ & & & \\
\hline
\end{tabular}

\section{Kesimpulan}

Pada penelitian ini telah diuji regresi data panel pengaruh variabel bebas yaitu Jumlah angkatan kerja dan Investasi modal luar negeri terhadap variabel respon yaitu PDRB provinsi di Indonesia tahun 2015-2017. Model terbaik yang didapat adalah fixed effect model dengan persamaan $Y^{*}=17,46997+C i+0,0001599 X 1+6,77 E-07 X 2$. Secara simultan model ini sesuai, dan secara parsial jumlah angkatan kerja serta investasi modal luar negeri masing-masing berpengaruh signifikan. Nilai adjusted $R^{2}$ adalah sebesar 99,8556\% yang berarti kedua variabel independent dapat menjelaskan variabel respon sebesar 99,8556\%. Model tersebut juga dianggap sesuai karena telah memenuhi asumsi normalitas residual, non multikolinieritas, homoskedastistas, serta non autokorelasi. Penelitian ini menunjukkan bahwa peningkatan jumlah angkatan kerja akan 
meningkatkan PDRB provinsi-provinsi di Indonesia sehingga diharapkan Indonesia benar-benar akan memiliki ekonomi yang kuat pada tahun 2045 ketika jumlah penduduk muda lebih banyak daripada penduduk tua. Selain itu ketika dibutuhkan investasi modal asing maka bisa juga kebijakan ini diterapkan karena dari model tampak bahwa meningkatnya penanaman modal asing maka akan mengakibatkan meningkatknya pula PDRB provinsi tersebut.

\section{Daftar Pustaka}

[1] Ambarsari, I. dan Purnomo, D. Studi Tentang Penanaman Modal Asing di Indonesia. Jurnal Ekonomi Pembangunan. 6:26-47. 2005.

[2] Kuwado, F. J., 2018. Jokowi Sebut Indonesia Jadi Salah Satu Negara Ekonomi Terkuat Tahun 2045. [Online] Available at: https://nasional.kompas.com $/ \mathrm{read} / 2018 / 07 / 10 / 23562681 /$ jokowi-sebut-indonesia-jadi-salah-satu-negara-ekonomiterkuat-tahun-2045 [Accessed 6 September 2018].

[3] Prasetyo, Z. K., 2014. Generasi Emas 2045 sebagai Fondasi Mewujudkan Siklus Peradaban Bangsa Melalui Implementasi Kurikulum 2013 di Sekolah Dasar. Pontianak, Universitas Tanjungpura Pontianak.

[4] Rika, D., 2014. Analsis Dampak Pengangguran Terhadap Kemiskinan di DKI Jakarta. Jurnal Pendidikan Ekonomi dan Bisnis, Volume 2, p. 67. 